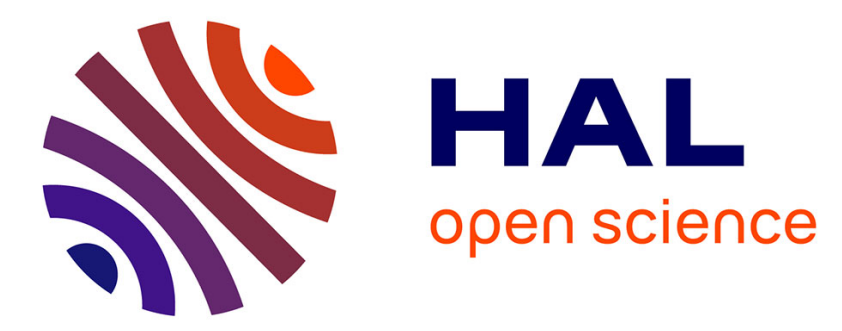

\title{
One-pot hydrosilylation-protodesilylation of functionalized diarylalkynes: a highly selective access to Z-stilbenes. Application to the synthesis of combretastatin A-4
}

Anne Giraud, Olivier Provot, Abdallah Hamze, Jean-Daniel Brion, Mouad Alami

\section{To cite this version:}

Anne Giraud, Olivier Provot, Abdallah Hamze, Jean-Daniel Brion, Mouad Alami. One-pot hydrosilylation-protodesilylation of functionalized diarylalkynes: a highly selective access to Zstilbenes. Application to the synthesis of combretastatin A-4. Tetrahedron Letters, 2008, 49 (7), pp.1107-1110. 10.1016/j.tetlet.2007.12.057 . hal-02394604

\author{
HAL Id: hal-02394604 \\ https://hal.science/hal-02394604
}

Submitted on 4 Dec 2019

HAL is a multi-disciplinary open access archive for the deposit and dissemination of scientific research documents, whether they are published or not. The documents may come from teaching and research institutions in France or abroad, or from public or private research centers.
L'archive ouverte pluridisciplinaire HAL, est destinée au dépôt et à la diffusion de documents scientifiques de niveau recherche, publiés ou non, émanant des établissements d'enseignement et de recherche français ou étrangers, des laboratoires publics ou privés. 


\title{
One-pot hydrosilylation-protodesilylation of functionalized diarylalkynes: a highly selective access to $Z$-stilbenes. Application to the synthesis of combretastatin A-4.
}

\author{
Anne Giraud ${ }^{1}$, Olivier Provot, ${ }^{1,2 *}$ Abdallah Hamzé ${ }^{1,2}$, Jean-Daniel Brion ${ }^{1,2}$ and Mouâd Alami ${ }^{2,1^{*}}$ \\ ${ }^{1}$ Univ Paris-Sud, BioCIS, UMR 8076, Laboratoire de Chimie Thérapeutique ; ${ }^{2}$ CNRS, BioCIS, UMR 8076, Laboratoire de Chimie \\ Thérapeutique, Faculté de Pharmacie, rue J.B. Clément, Châtenay-Malabry, F-92296, France
}

\begin{abstract}
An efficient stereoselective synthesis of Z-stilbenes has been developed from diarylalkynes via a new hydrosilylationprotodesilylation process. Scope and limitation of this method to prepare stereoselectively a wide range of (Z)-stilbenes in a one-pot way is presented. A concise application to the preparation of combretastatin A-4 (CA-4), a vascular targeting agent inhibitor of tubulin polymerisation is described.
\end{abstract}

A large number of stilbene (1,2-diphenylethylene) derivatives have been isolated from various plant species and exhibit a large panel of biological activities such as, antineoplastic, antiangiogenesis, cytotoxic and inhibitory of cell proliferation. ${ }^{1}$ Beside trans stilbene derivatives and one of their leader, Resveratrol, a large number of their cis homologues were isolated, synthesized and evaluated. The most promising of these stilbenes thus far are combretastatins and particularly, the combretastatin A-4 (CA-4), due to its biological activities combined to its structural simplicity (Scheme 1). ${ }^{2}$
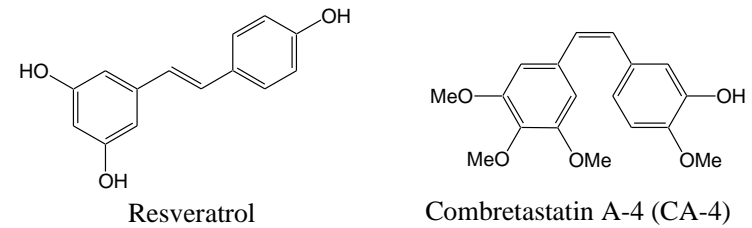

Scheme 1

If the access of trans stilbenes is well-documented, ${ }^{3}$ there are only few methodologies that give access to their cis counterparts. The most popular approach is based on the $Z$ selective-Lindlar ${ }^{4}$ semi reduction of diarylalkynes but suffer from several drawbacks as $(Z)$ to $(E)$ isomerisation, over reduction to the alkane making purifications tedious and problems with reproductibility.

As a part of our research devoted to anticancer agents, ${ }^{5}$ that target tubulin, ${ }^{6}$ we wished to synthesize the natural product $\mathrm{CA}-4$ as a reference molecule since, to our knowledge; CA-4 is not commercially available anymore. The chemical synthesis of CA-4 has been tackled in a variety of ways. ${ }^{1 b, 7}$ while these reactions are suitable methods, many of them either display low stereoselectivity or do not tolerate sensitive functionalities. Therefore, alternative routes for the synthesis of CA-4 are welcome. A recent work describing the synthesis of CA-4 and analogues by hydrolysis of Ti(II)-alkynes complexes, ${ }^{8}$ prompted us to publish our preliminary results in the Z-semi reduction of alkynes field.

Recently, we showed that heterogeneous platinum oxide $\left(\mathrm{PtO}_{2}\right)$ is a very efficient catalyst for the hydrosilyilation of para and ortho substituted diarylalkynes. The $\mathrm{H}-\mathrm{Si}$ bond addition proceeds in a stereoselective cis-fashion ${ }^{9}$ and the regioselectivity of the reaction was found to be governed by ortho-directing effects $(\mathrm{ODE})^{10}$ rather than the nature of the platinum catalysts. We reasoned that this efficient hydrosilylation of internal arylalkynes could be efficiently exploited to give, after linkage of the $\mathrm{C}-\mathrm{Si}$ bond, $Z$-stilbenes of high biological interest. We present in this communication a convenient one-pot procedure for the $Z$-selective semi reduction of diarylalkynes via a hydrosilylation-protodesilylation sequence.

To define optimal reaction conditions, we have studied initially the hydrosilylation of diarylalkynes $\mathbf{1 a}$ and $\mathbf{1 b}$ as

*Corresponding authors. olivier.provot@u-psud.fr and/or mouad.alami@u-psud.fr

Keywords : combretastatin A4, (Z)-stilbenes, hydrosilylation, desilylation, platinum 


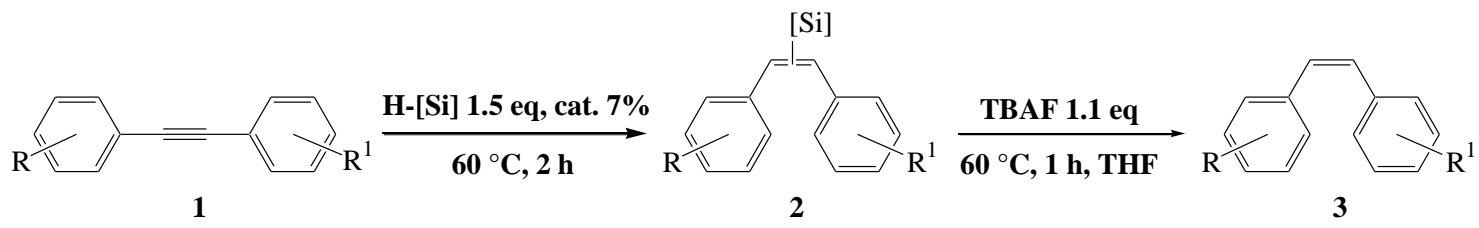

Table 1. Hydrosilylation-protodesilylation sequence; access to Z-stilbenes $\mathbf{3}$

\begin{tabular}{|c|c|c|c|c|c|c|c|c|}
\hline entry & diarylalkyne 1 & $\mathrm{H}-[\mathrm{Si}]$ & catalyst & yield & of $2^{\mathrm{b}}(\%)$ & \multicolumn{2}{|c|}{ yield $^{\mathrm{a}}$ of $\mathbf{3}(\%)$} & $Z / E$ ratio $^{c}$ \\
\hline 1 & $\begin{array}{c}\text { 1a } \mathrm{R}=4-\mathrm{OMe} \\
\mathrm{R}^{1}=\mathrm{H}\end{array}$ & 1: $\mathrm{HSiEt}_{3}$ & $\mathrm{PtO}_{2}$ & $2 a-1$ & 97 & $\mathbf{3 a}$ & 58 & $85 / 15$ \\
\hline 2 & $"$ & 2: $\mathrm{HSiPh}_{2} \mathrm{Me}$ & $"$ & $2 a-2$ & 93 & $"$ & 49 & $100 / 0$ \\
\hline 3 & $"$ & 3: $\mathrm{HSi}(\mathrm{OEt})_{3}$ & $"$ & $\mathbf{2 a - 3}$ & 70 & $"$ & 80 & $100 / 0$ \\
\hline 4 & $"$ & 4: HSiOEtMe & $\mathrm{PtO}_{2}$ & $2 a-4$ & 86 & $"$ & 90 & $100 / 0$ \\
\hline 5 & $"$ & $"$ & $\mathrm{PtCl}_{2}$ & $2 a-4$ & 44 & $"$ & $\mathrm{nd}^{\mathrm{d}}$ & $\mathrm{nd}^{\mathrm{d}}$ \\
\hline 6 & $"$ & $"$ & $\mathrm{Pt} / \mathrm{C}$ & $2 a-4$ & 38 & $"$ & - & - \\
\hline 7 & $"$ & $"$ & $\mathrm{PtCl}_{4}$ & $2 a-4$ & 56 & " & - & - \\
\hline 8 & $"$ & $"$ & $\mathrm{H}_{2} \mathrm{PtCl}_{6}$ & $2 a-4$ & mixture & $"$ & - & - \\
\hline 9 & $\begin{array}{c}\text { 1b } \mathrm{R}=2,3,4-\mathrm{OMe}, \\
\mathrm{R}^{1}=\mathrm{H}\end{array}$ & 4: $\mathrm{HSiOEtMe}_{2}$ & $\mathrm{PtO}_{2}$ & $2 b-4$ & 87 & $3 \mathbf{b}$ & 77 & $98 / 2$ \\
\hline 10 & $"$ & 3: $\mathrm{HSi}(\mathrm{OEt})_{3}$ & $"$ & $2 b-3$ & 78 & & 84 & $98 / 2$ \\
\hline 11 & $"$ & 4: $\mathrm{HSiOEtMe}_{2}$ & $"$ & $2 b-4$ & 87 & & $88^{\mathrm{e}}$ & $100 / 0$ \\
\hline 12 & $\begin{aligned} \text { 1c } \mathrm{R} & =2,3,4-\mathrm{OMe}, \\
\mathrm{R}^{1} & =3-\mathrm{OH}, 4-\mathrm{OMe}\end{aligned}$ & $"$ & $"$ & $2 c-4$ & $70^{\mathrm{f}}$ & CA-4 & 69 & $100 / 0$ \\
\hline
\end{tabular}

${ }^{a}$ Isolated yield.

${ }^{b}$ Mixture of regioisomers (ratio not determined).

${ }^{c} Z$ : $E$ Ratios quoted as a percentage composition of total yield as estimated from ${ }^{1} \mathrm{H}$ NMR spectra.

${ }^{d}$ Not determined.

${ }^{e}$ Protodesilylation was achieved at RT.

${ }^{f} 4$ eq of $\mathrm{HSiOEtMe}_{2}$ were required.

model substrates and their subsequent desilylation. The results are summarized in Table 1. Preliminary experiment was carried out using $\mathrm{HSiEt}_{3}(1.5 \mathrm{eq}), \mathrm{PtO}_{2}(7 \mathrm{~mol} \%)$ at 60 ${ }^{\circ} \mathrm{C}$ in the absence of solvent as we previously reported. ${ }^{9}$ In this case, a mixture of vinylsilanes was obtained with a quantitative yield after purification on silica gel. However, the desilylation of the vinylsilanes mixture using TBAF $(1.5 \mathrm{eq})$ at $60{ }^{\circ} \mathrm{C}$ afforded a moderate yield of $Z-3 \mathbf{a}$ together with significant amounts of $E-3 \mathbf{a}$ (entry 1). A survey of the sequence hydrosilylation-protodesilylation sequence of alkyne 1a under the same conditions in the presence of other representative silanes, including $\mathrm{HSiPh}_{2} \mathrm{Me}, \mathrm{HSi}(\mathrm{OEt})_{3}$ and $\mathrm{HSiOEtMe}_{2}$ was conducted (entries 2-4). In these cases, we were pleased to observe the formation of a single Z-3a stereoisomer whatever the nature of the silane used and the better overall yield was obtained with the non-toxic ${ }^{11} \mathrm{HSiOEtMe}_{2}$ (77\% for the two steps, entry 4). Encouraged by this result, the effect of $\mathrm{PtCl}_{4}, \mathrm{PtCl}_{2}$ and $\mathrm{Pt} / \mathrm{C}$ on the outcome of the hydrosilylation reaction was investigated. None of these platinum catalysts led to better results than those achieved with $\mathrm{PtO}_{2}$ (entries 5-7). One can note that $\mathrm{H}_{2} \mathrm{PtCl}_{6}$ (Speier's catalyst), which is considered to be the catalyst of choice for cis- hydrosilylation of internal alkynes ${ }^{12}$ was not efficient and led to a complex mixture (entry 7). Having defined the best conditions $\left[\mathrm{PtO}_{2}(7 \mathrm{~mol} \%), \mathrm{HSiOEtMe}_{2}(1.5 \mathrm{eq}), 60{ }^{\circ} \mathrm{C}\right.$ then TBAF $\left.(1.5 \mathrm{eq}), 0^{\circ} \mathrm{C}\right] \mathrm{Z}$-stilbene $3 \mathrm{~b}$ bearing a 3,4,5trimethoxyaryl moiety was prepared and isolated with good yield (entry 9). Careful inspection of the ${ }^{1} \mathrm{H}$ NMR spectrum of the crude reaction mixture indicated that the stilbene 3b was formed in a 98:2/Z:E ratio. A similar result was obtained when using $\mathrm{HSi}(\mathrm{OEt})_{3}$ instead of $\mathrm{HSiOEtMe}_{2}$ (entry 10). Finally, the best result in terms of yield and Zstereoselectivity was observed when the desilylation step of the vinylsilane $\mathbf{2 b - 4}$ was achieved at room temperature (entry 11). In this case, $Z$-stilbene $\mathbf{3 b}$ was obtained as a single $Z$ stereoisomer in a $77 \%$ overall isolated yield (based on alkyne 1b). We then applied this two stages process to prepare the target natural product $\mathrm{CA}-4^{13}$ from diarylalkyne 1c. We were delighted to observe that the hydrosilylation-protodesilylation proceeded extremely efficiently to give the desired CA-4 as a single $Z$-isomer with good yield (entry 12).

From a practical point of view of the synthetic chemist, we explored the process in a one-pot manner. Thus, after the 
hydrosilylation step, the excess of the volatile $\mathrm{HSiOEtMe}_{2}$ was removed to achieve the protodesilylation step with TBAF ( 3 eq) at $0{ }^{\circ} \mathrm{C}$ for a better $Z$-stereoselectivity. Scope and limitations of this one-pot process using various functionalized diarylalkynes $\mathbf{1}$ are summarized in Table 2.

Table 2. One-pot access to $Z$-stilbenes $\mathbf{3}$ from diarylalkynes 1

alkynes

${ }^{a} Z: E$ Ratios quoted as a percentage composition of total yield as estimated from ${ }^{1} \mathrm{H}$ NMR spectra.

${ }^{b}$ Isolated yield.

${ }^{c}$ Unoptimized yield.

Diarylalkynes 1a, 1d-f substituted with an electron donating group (OMe, Me) have been transformed successfully to their corresponding stilbenes $\mathbf{3}$ in good yields (entries 1-4). It should be noted that the position of the substituent on the aromatic ring had no influence on the Z-stereochemistry of the stilbenes formed (entries 1-3). A similar result (total $Z$-stereocontrol) has been obtained from $1 \mathrm{~g}$ bearing a pivaloyl ester function but with a moderate unoptimized $49 \%$ yield (entry 5). We were also pleased to observe that halogenated substituted arylalkynes $\mathbf{1 h}$ and $\mathbf{1 i}$ afforded the expected stilbenes $\mathbf{3 h}$ and $\mathbf{3 i}$ respectively with acceptable yields and again as single $Z$ stereoisomers (entries 6 and 7). When the push-pull diarylalkynes $\mathbf{1 j}$ was employed as a substrate, it was found that the $Z$-stereochemistry of this one-pot process was slightly reduced. In this case, traces of the $E$-stilbene were detected by ${ }^{1} \mathrm{H}$ NMR spectroscopy. This $\mathrm{PtO}_{2}$-catalyzed hydrosilylation-protodesilylation one-pot process can be performed also with alkyne $1 \mathbf{k}$ bearing a methoxycarbonyl group as illustrated in entry 9 . In this case again a total Zstereochemistry associated with a nearly quantitative yield was observed (95\%).

We next embarked on the utilization of this process for the conversion of 3,4,5-trimethoxyarylalkynes to their corresponding Z-stilbenes, analogues of CA-4. Starting from 3,4,5-trimethoxyarylalkynes $\mathbf{1 l}$ and $\mathbf{1 m}$ bearing an ortho or a para methoxy group respectively, it was noted that the 3,4,5 trimethoxyaryl unit smoothly affected the $Z$ stereoselectivity (>95\%, entries 10 and 11 ) providing 31 and $\mathbf{3} \mathbf{m}^{14}$ in good yields. Similarly, we succeeded in the one-pot preparation of known biologically active analogues of $\mathbf{C A - 4}, \mathbf{3} \mathbf{n}^{15}$ and $\mathbf{3 o}^{16}$ within good yields and high $Z$-stereocontrol (entries 12 and 13).

On account of the large scope of this one-pot procedure, we then attempted to synthesized CA-4 from the corresponding 1c having a free phenolic function. Because of the side silylation of the phenol moiety, the desilylation step was conducted at $60{ }^{\circ} \mathrm{C}$. As showed in entry 14, CA-4 was obtained with fortunately an excellent $Z$ stereoselectivity (Z:E/90:10) and a good yield. Careful separation on silica gel afforded pure CA-4 which could be used as reference for biological evaluation of analogues that would be reported in due course.

In summary, we have developed a new mild and efficient method for the synthesis of $Z$-stilbenes from diarylalkynes. This method is complementary to the existing procedures and sometimes could be the method of choice because of its chemoselectivity, simplicity and its excellent $Z$ stereoselectivity. The ease of which several $Z$-stilbenes were obtained with a total $Z$-stereocontrol and good yields encouraged us to prepare efficiently by this way the natural stilbene CA-4. Moreover, we demonstrated too that this hydrosilylation-protodesilylation sequence could be achieved in a one- pot way from various diarylalkynes.

\section{Acknowledgments}

The CNRS is gratefully acknowledged for financial support of this research and the MNSER for a doctoral fellowship to A.G.

\section{References}


${ }^{1}$ (a) Jang, M.; Cai, L.; Udeani, G. O.; Slowing, K. V.; Thomas, C. F.; Beecher, C. W. W.; Fong, H. H. S.; Farnworth, R. N.; Kinghorn, A. D.; Metha, R. G.; Moon, R. C.; Pezzuto, J. M. Science 1997, 275, 218. (b) Pettit, G. R.; Rhodes, M. R.; Herald, D. L.; Hamel, E.; Schmidt, J. M.; Pettit, R. K. J. Med. Chem. 2005, 48, 4087 and references cited therein.

2 (a) Pettit, G. R.; Cragg, G. M.; Singh, S. B. J. Nat. Prod. 1987, 50, 386. (b) Pettit, G. R.; Singh, S. B.; Hamel, E.; Lin, C. M.; Alberts, D. S.; Garcia-Kendall, D.; Experientia 1989, 45, 209. (c) Pettit, G. R.; Singh, S. B.; Boyd, M. R.; Hamel, E.; Pettit, R. K.; Schmidt, J. M.; Hogan, F. J. Med. Chem. 1995, 38,1666

${ }^{3}$ Ferré-Filmon, K.; Delaude, L.; Demonceau, A.; Noels, A. F. Coord. Chem. Rev. 2004, 248, 2323.

4 (a) Lindlar, H. Helv. Chim. Acta 1952, 35, 446. (b) Lindlar, H.; Dubuis, R. Org. Synth. 1973, 5, 880.

${ }^{5}$ Le Bras, G.; Radanyi, C.; Peyrat, J.-F.; Brion, J.-D.; Alami, M.; Marsaud, V.; Stella, B.; Renoir, J.-M. J. Med. Chem. 2007, 50, http://dx.doi.org/10.1021/jm0707774.

${ }^{6}$ Provot, O.; Giraud, A.; Peyrat, J.-F.; Alami, M.; Brion, J.-D. Tetrahedron Lett. 2005, 46, 8547.

${ }^{7}$ (a) Robinson, J. E.; Taylor, R. J. K. Chem. Commun. 2007, 1617. (b) Harrowven, D. C.; Guy, I. L.; Howell, M.; Packham, G. Synlett 2006, 2977. (c) Gaukroger, K.; Hadfield, J. A.; Hepworth, L. A.; Lawrence, N. J.; McGown, A. T. J. Org. Chem. 2001, 66, 8135. (d) Lawrence, N. J.; Abdul Ghani, F.; Hepworth, L. A.; Hadfield, J. A.; McGown, A. T.; Pritchard, R. G. Synthesis 1999, 1656. (e) Fürstner, A.; Nikolakis, K. Liebigs, Ann. 1996, 2107.

${ }^{8}$ Lara-Ochoa, F.; Espinosa-Pérez, G. Tetrahedron Lett. 2007, 48, 7007

${ }^{9}$ Hamze, A.; Provot, O.; Brion, J.-D.; Alami, M. Synthesis, 2007, 2025. (b) Hamze, A.; Provot, O.; Alami, M.; Brion, J.-D. Org. Lett. 2005, 7, 5625.

${ }^{10}$ (a) Liron, F.; Le Garrec, P.; Alami, M. Synlett 1999, 246. (b) Alami, M.; Liron, F.; Gervais, M.; Peyrat, J.-F.; Brion, J.-D. Angew. Chem. Int. Ed. 2002, 41, 1578. (c) Liron, F.; Gervais, M.; Peyrat, J.-F.; Alami, M.; Brion, J.-D. Tetrahedron Lett. 2003, 44, 2789. (d) Bujard, M.; Ferri, F.; Alami, M. Tetrahedron Lett. 1998, 39, 4243. (e) Hamze, A.; Provot, O.; Brion, J.-D.; Alami, M. J. Org. Chem. 2007, 72, 3868.

${ }^{11}$ Dodd, D. E.; Stuart, B. O.; Rothenberg, S. J.; Kershaw, M.; Mann, P. C.; James, J. T.; Lam, C. W. Inhal. Toxicol. 1994, 6, 151.

12 Speier's catalyst is well-known to provide cis-addition processes for internal and terminal alkynes; see: Tsipis, C. A. J. Organomet. Chem. 1980, 187, 427.

${ }^{13}$ Procedure for the synthesis of CA-4: In a $10 \mathrm{~mL}$ flask, $\mathrm{PtO}_{2}(10 \mathrm{mg}, 0.0035 \mathrm{mmol})$ and arylalkyne 1c $(0.5$ mmol) were placed under nitrogen atmosphere. Dimethylethoxysilane (304 $\mu \mathrm{L}, 2 \mathrm{mmol})$ was introduced via syringe and the mixture was stirred at $60{ }^{\circ} \mathrm{C}$ in an oil bath for $1 \mathrm{~h}$. The residue was concentrated and then purified by column chromatography over silica gel to yield the vinylsilanes as a mixture of regioisomers (147 $\mathrm{mg} ; 70 \%)$. The mixture of vinylsilanes $(147 \mathrm{mg}, 0.35$ mmol) was treated with TBAF in THF $(1 \mathrm{~mL}, 1 \mathrm{~N})$ at 60 - $\mathrm{C}$ for $1 \mathrm{~h}$. After concentration in vacuo, the crude product was purified by column chromatography $\left(\mathrm{SiO}_{2}\right.$,
Cyclohexane/ EtOAc : 70/30) to afford CA-4 as a single Z-stereoisomer (75 mg; 69\%). TLC: $\mathrm{R}_{f} 0.46$ (Cyclohexane/EtOAc : 70/30, 1/1, $\mathrm{SiO}_{2}$ ). ${ }^{1} \mathrm{H}$ NMR (300 $\left.\mathrm{MHz} \mathrm{CDCl}_{3}\right) \delta 3.70$ (s, 6H), 3.84 (s, 3H), 3.86 (s, 3H), 5.50 (brs, $1 \mathrm{H}, \mathrm{OH}), 6.40(\mathrm{~d}, 1 \mathrm{H}, J=12.1 \mathrm{~Hz}), 6.47(\mathrm{~d}$, $1 \mathrm{H}, J=12.1 \mathrm{~Hz}), 6.53(\mathrm{~s}, 2 \mathrm{H}), 6.72(\mathrm{~d}, 1 \mathrm{H}, J=8.2 \mathrm{~Hz})$, $6.80(\mathrm{dd}, 1 \mathrm{H}, J=8.2 \mathrm{~Hz}, J=1.8 \mathrm{~Hz}), 6.92(\mathrm{~d}, 1 \mathrm{H}, J=1.8$ $\mathrm{Hz}) .{ }^{13} \mathrm{C} \mathrm{NMR}\left(75 \mathrm{MHz}, \mathrm{CDCl}_{3}\right) \delta 55.9(2 \mathrm{C}), 56.1,60.9$, 106.0 (2 C), 110.3, 115.0, 121.1, 129.0, 129.5, 130.6, 132.7, 137.1, 145.2, 145.8, 152.8 (2 C).

${ }^{14}$ Cushman, M.; Nagarathnam, D.; Gopal, D.; Chakraboti, A. K.; Lin, C. M.; Hamel, E. J. Med. Chem. 1991, 34, 2579.

15 Lin, C. M.; Singh, S. B.; Chu, P. S.; Dempcy, R. O.; Schmidt, J. M.; Pettit, G. R.; Hamel, E. Mol. Pharmacol. 1988, 34, 200.

${ }^{16}$ Maya, A. B.; Del Rey, B.; De Clairac, R. P., Caballero, E.; Barasoain, I.; Andreu, J. M.; Medarde, M. Bioorg. Med. Chem. Lett. 2000, 10, 2549. 